Apidologie, 1983, 14 (3), 197-204.

\title{
OBSERVATIONS ON MITES OF THE ASIAN HONEYBEE SPECIES (Apis cerana, Apis dorsata, Apis florea)
}

\author{
N. KOENIGER, G. KOENIGER \\ Institut für Bienenkunde (Polytechnische Gessellschaft) \\ Fachbereich Biologie der J. W. Goethe-Universität \\ Frankfurt/Main, Karl-v.-Frisch-Weg 2, 6370 Oberursel \\ M. DELFINADO-BAKER \\ Bioenvironmental Bee Laboratory, Blgd. 476, BARC-East, \\ Beltsville, Maryland 20705
}

\begin{abstract}
SUMMARY
The relationship of the parasitic mites to Asian honey bees (Apis cerana, A. dorsata, A. florea) was investigated in Sri Lanka. The significant findings are as follows : In Sri Lanka examination of capped brood cells showed that Varroa jacobsoni preferred drone cells and that the mite reproduction occurs only in drone cells of $A$. cerana. Further observations in Java revealed that Varroa infested capped drone cells of $A$. cerana are not opened by the bees when a pupa dies thus the mites also die. This presumably keeps the Varroa infestation of $A$. cerana at a lower level than in $A$. mellifera because Varroa reproduces in both worker and drone brood cells of $A$. mellifera. Other mite pests of Asian honey bees in Sri Lanka are as follows : 1) Euvarroa sinhai was found only in drone brood cells and on adults of $A$. florea. 2) Tropilaelaps koenigerum was found on adult bees as well as in combs of $A$. dorsata. 3) Neocypholaelaps indica, a pollen feeder and phoretic on bees, was present in considerable numbers on all species of Asian honeybees (A. cerana, A. dorsata, A. florea). A. dorsata and A. florea are new host records for $N$. indica.
\end{abstract}

\section{INTRODUCTION}

After the Western honeybee Apis mellifera was introduced into many countries of Asia these colonies and their descendants soon became infested by mites originally associated with the Asian honeybees and proved to be disastrous for the imported bees. One species, Varroa jacobsoni has spread to the West and is today a serious problem of beekeeping in Europe, Africa and South America. Consequently there is much recent information available on Asiatic mite 
infestations of $A$. mellifera. On the Asian honeybees the same mites apparently do not cause noticeable damage, so the relation between them and their natural host is nearly unknown. The observations presented here are an initial step in this direction. They are based entirely on native Asiatic bees in their natural habitat where $A$. mellifera never was established.

\section{MATERIAL AND METHODS}

For the detection of mites adult bees, brood and combs of all three species were collected in winter 80/81. Most of the bee samples were taken from the Anuradhapura district (North Central Province), Sri Lanka. There was a dense population of $A$. florea and $A$. dorsata colonies which were collected at night in their natural nesting places. The samples of $A$. cerana were taken from modern wooden hives, in which the colonies were kept by beekeepers. Some samples of $A$. cerana were collected in Sukabumi (Java), Indonesia in May 1981.

For detecting the mites the methods of the diagnosis of $V$. jacobsoni in colonies of A. mellifera (RITTER and RUTTNER 1980) were modified according to the facilities available.

1. Washing of adult bees in petrol :

The bees were soaked in regular petrol for $30 \mathrm{~min}$. ( $1000 \mathrm{bees} / 500 \mathrm{ml})$. Then the container was carefully shaken by hand for $10 \mathrm{~min}$. Finally the contents were poured through a wire screen (mesh $4 \times 4 \mathrm{~mm}$ ) to filter out the bees. For holding back the mites, the petrol was passed through a cotton cloth.

2. Rinsing of combs with detergent water:

Combs or pieces of it were carefully rinsed 3 times with detergent water $(2 \mathrm{ml}$ detergent/ $/ 1)$. The mites were then sieved out by a cotton cloth.

\section{Inspection of capped brood cells :}

The brood cells were carefully uncapped and the walls, larvae and pupae were examined carefully under a preparation microscope $(10 \mathrm{x})$. The light had to be focused directly into the cell, for the mites to be seen.

\section{Collection of foraging bees at a feeding dish:}

Honeybees were trained to a feeding dish where they were carefully examined for mites. Infested bees were collected and examined under a microscope. This method was used in cases where the colonies were inaccessible to us.

\section{RESULTS}

\section{A. Varroa jacobsoni Oudemans (1904) (Fig. 1)}

Samples of adult bees were collected from $6 \mathrm{~A}$. cerana colonies in Anuradhapura district; five of them were infested with $V$. jacobsoni (Table 1).

The examination of capped brood cells of $A$. cerana showed that this mite preferred drone cells. Furthermore only in drone cells does the reproduction take 


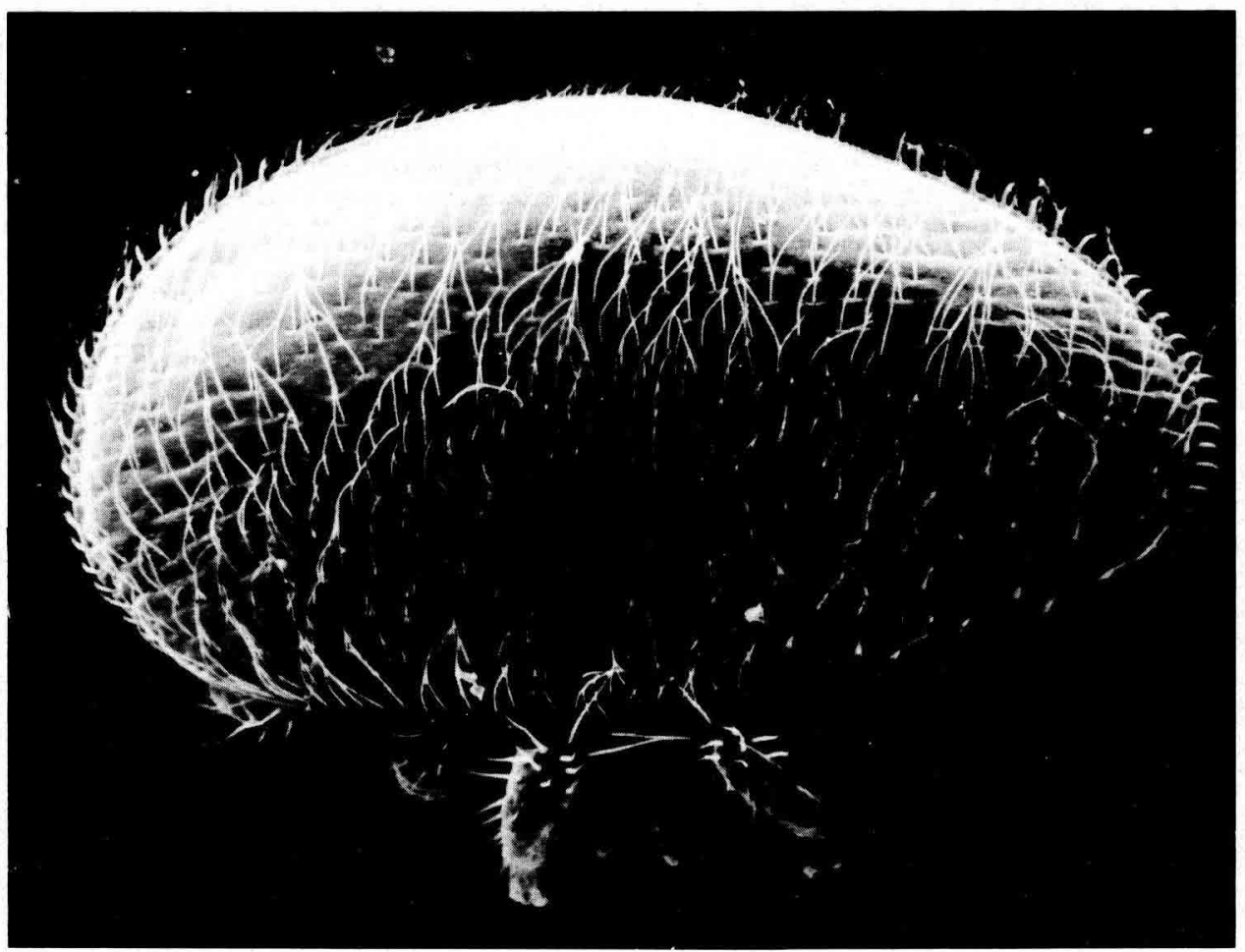

FIG. 1. - Varroa jacobsoni, female, dorsale view, SEM $55 \times$ (by W. E. Styer)

TABL. 1. - Incidence of $\mathrm{V}$. jacobsoni in brood cells of workers and adult A. cerana in Amuradhapura (Sri Lanka)

\begin{tabular}{|c|c|c|c|c|}
\hline \multirow[b]{2}{*}{ Colony } & \multicolumn{2}{|c|}{ Worker Cells } & \multicolumn{2}{|c|}{ Petrol Washing of Adults } \\
\hline & $\begin{array}{c}\text { Number } \\
\text { of worker cells }\end{array}$ & $\begin{array}{l}\text { Number } \\
\text { of mites }\end{array}$ & $\begin{array}{c}\text { Number } \\
\text { of adult worker }\end{array}$ & $\begin{array}{l}\text { Number } \\
\text { of mites }\end{array}$ \\
\hline CW 1 & 400 & 0 & 850 & 1 \\
\hline CW 2 & 80 & 6 & 550 & 2 \\
\hline CW 3 & 138 & 7 & 600 & 0 \\
\hline $\mathrm{CW} 4$ & 300 & 0 & 700 & 6 \\
\hline CW 5 & 300 & 0 & 450 & 26 \\
\hline CW 6 & 300 & 0 & 500 & 2 \\
\hline
\end{tabular}


place. All mites found in worker brood cells had no offspring (KOENIGER et al. 1981). Inspection of brood in Java also confirmed the results of the previous report (Table 2).

TABL. 2. - Incidence of $\mathrm{V}$. jacobsoni on A. cerana in Java

\begin{tabular}{|c|c|c|c|c|}
\hline \multirow[b]{2}{*}{ Colony } & \multicolumn{4}{|c|}{ Inspected sealed brood cells } \\
\hline & $\begin{array}{c}\text { Number } \\
\text { of worker cells }\end{array}$ & $\begin{array}{l}\text { Number } \\
\text { infested }\end{array}$ & $\begin{array}{c}\text { Number } \\
\text { of drone cells }\end{array}$ & $\begin{array}{l}\text { Number } \\
\text { infested }\end{array}$ \\
\hline L. 1 & 60 & 4 & 36 & 30 \\
\hline L. 2 & 43 & 0 & 30 & 1 \\
\hline L. 3 & 50 & 0 & 50 & 14 \\
\hline L. 4 & 60 & 1 & 51 & 1 \\
\hline L. 5 & 30 & 0 & 51 & 4 \\
\hline & \multicolumn{2}{|c|}{$\begin{array}{l}\text { No reproductive } \\
\text { stages of varroa } \\
\text { were found } \\
\text { in worker cells }\end{array}$} & \multicolumn{2}{|c|}{$\begin{array}{l}\text { All drone cells contained } \\
\text { reproductive of varroa }\end{array}$} \\
\hline
\end{tabular}

In Java two colonies had old drone cells which were not uncapped by the worker bees even though they contained dead pupae that were completely dried. In 74 of these cells, 362 dead Varroa mites were found. Apparently these mites also died with the drone pupae on which they had fed in the sealed cell long before our inspection.

\section{B. Euvarroa sinhai DelfinAdo and BAKER (1974) (Fig. 2)}

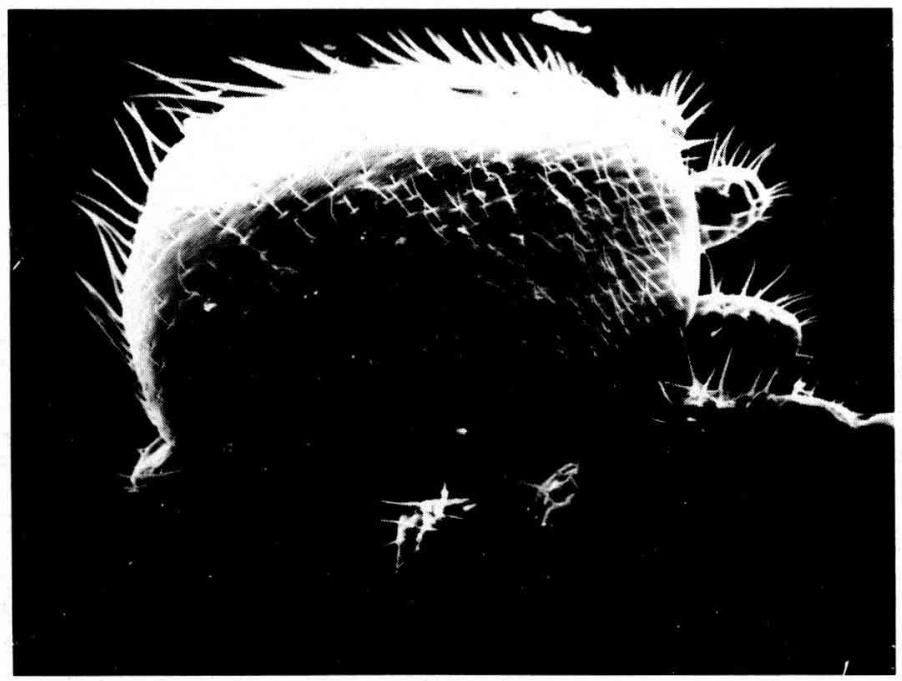

FIG. 2. - Euvarroa sinhai, female, SEM $75 \times($ by W. E. Styer)

Euvarroa sinhai was found in all the colonies of $A$. florea that were examined. The number of mites per colony was very small. No Euvarroa was 
found in worker cells! The results of brood examinations and washing of adult bees are given in table 3 .

TABL. 3. -- Incidence of E. sinhai in brood cells and adults of A. florea

\begin{tabular}{l|cc|cc|cc}
\hline \hline \multirow{2}{*}{ Colony } & \multicolumn{2}{|c|}{ Petrol washing of adults } & \multicolumn{4}{c}{ Cell inspection } \\
\cline { 2 - 6 } & $\begin{array}{c}\text { Number } \\
\text { of workers }\end{array}$ & $\begin{array}{c}\text { Number } \\
\text { of mites }\end{array}$ & $\begin{array}{c}\text { Number } \\
\text { of worker } \\
\text { cells } \\
\text { examined }\end{array}$ & $\begin{array}{c}\text { Number } \\
\text { infested }\end{array}$ & $\begin{array}{c}\text { Number } \\
\text { of drone } \\
\text { cells } \\
\text { examined }\end{array}$ & $\begin{array}{c}\text { Number } \\
\text { infested }\end{array}$ \\
\hline$F_{1}$ & 5,500 & 2 & - & - & - & - \\
$F_{2}$ & 10,000 & 58 & 244 & 0 & 134 & - \\
$F_{3}$ & 3,000 & 40 & 400 & 0 & - & 15 \\
$F_{4}$ & 12,000 & 63 & 400 & 0 & 133 & 0 \\
$F_{5}$ & 2,500 & 1 & 400 & 0 & 0 & 1 \\
$F_{6}$ & 4,000 & 3 & 21 & &
\end{tabular}

\section{Tropilaelaps koenigerum DelfinAdo-BAKER and BAKER (1982)}

Tropilaelaps koenigerum was only found in colonies of $A$. dorsata. We observed it on adult bees as well as on the combs in five of six colonies.

D. Neocypholaelaps indica Evans (1963) (Fig. 3)

This mite was found in all three species of Asian bees : A. cerana, dorsata and florea. It was previously recorded from $A$. cerana and Eucalyptus flowers from

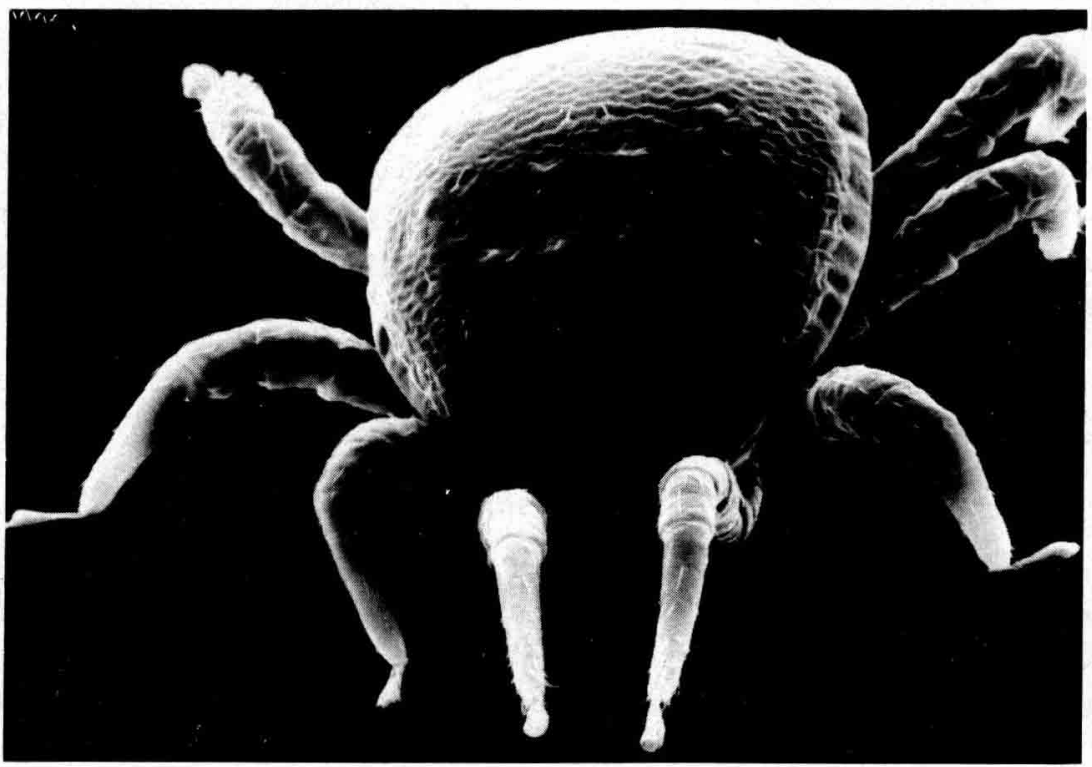

FIG. 3. - Neocypholaelaps indica, female, SEM $135 \times$ (by W. E. Styer) 
India, Nepal and Ceylon. $A$. dorsata and $A$. florea are thus new host records. Neocypholaelaps indica is most likely a pollen feeder and the females are phoretic on bees. The mites were first noticed on foragers of $A$. florea at a feeding dish. In $A$. cerana the mites were found mainly attached to foraging bees in three of 13 colonies. A few mites were also found on the combs. In one $A$. dorsata colony nearly 2000 Neocypholaelaps were found by washing the adult bees in petrol while only a few mites were found on the combs of this or other colony. The examination of four other $A$. dorsata colonies revealed no $N$. indica.

TABL. 4. - The honeybee mites and their natural hosts in Sri Lanka

\begin{tabular}{c|ccc}
\hline \hline \multirow{2}{*}{ Host species } & Apis florea & Apis dorsata & Apis cerana \\
\hline \multirow{4}{*}{$\begin{array}{c}\text { Mite } \\
\text { species }\end{array}$} & $\begin{array}{c}\text { Euvarroa } \\
\text { sinhai }\end{array}$ & - & $\begin{array}{c}\text { Tropilaelaps } \\
\text { koenigerum }\end{array}$ \\
\cline { 2 - 4 } & - & - & - \\
\cline { 2 - 4 } & & Neocypholaelaps indica & jacobsoni \\
\cline { 2 - 4 }
\end{tabular}

\section{E. Other mites}

Suidasia medanensis OUdEMAns (1924). This mite was found in combs of $A$. cerana and $A$. florea for the first time. It was collected originally from a bee nest (Xylocopa sp.) from Sumatra. Hughes (1976) recorded Suidasia medanensis from rice bran, cowpeas, groundnuts, dead mosquitoes, and from copra. It is possibly a commensal in nests of bees. Hypopi (phoretic deutonymphs) of Acaridae were found on $A$. cerana and $A$. dorsata. Most likely these are undescribed species. Adults of undetermined species of Uropodidae were found also on $A$. dorsata.

\section{DISCUSSION}

In Sri Lanka up to now there are no colonies of $A$. mellifera. Under these conditions $V$. jacobsoni is restricted to $A$. cerana and reproduces in drone cells only where they are found 10 times more frequently than in worker cells. This preference may be responsible for keeping the infestation on a lower level than in $A$. mellifera, where it feeds and reproduces in both worker and drone cells. The 
observation in Sukabumi shows an additional way of regulation of Varroa by $A$. cerana : drone cells are not uncapped by the bees when a pupa dies. So in case of the killing of drone pupae by a high infestation of Varroa, the mites themselves die also. In Sri Lanka the infestation is so low that Varroa was not known to be present before our examinations.

Euvarroa sinhai is restricted to A. florea. This mite seems to be more " advanced " than Varroa as it reproduces on drone brood and does not enter into worker brood cells at all. Our finding confirms a similar report of $E$. sinhai in Thailand (AKaratanakul 1976). This is the first report of Euvarroa in Sri Lanka.

In $A$. dorsata a new species of mites, Tropilaelaps koenigerum was found in Sri Lanka. This mite too is restricted only to one species. It was seen on adults and in brood cells. Its reproduction cycle still is unknown but it seems very likely that it feeds on haemolymph as Varroa and Euvarroa.

Neocypholaelaps indica is a pollen feeder and is present in all three Sri Lankan honeybee species. It seems that the kind of food is important for the distribution of the pests among the three Asian honeybee species. Not only the pollen feeders are infesting all three species but also the "waxfeeder ", the wax moth (Galleria mellonella).

Apis mellifera which is imported to many countries in Asia seems to have no natural protection against the transition of parasitic mites feeding on bee haemolymph. Thus $V$. jacobsoni and apparently $T$. clarae can cause the death of a colony once it is infested and not treated by beekeepers. It is not known whether E. sinhai and T. koenigerum are able to infest Apis mellifera.

Received for publication in April 1983.

\section{ACKNOWLEDGEMENTS}

We thank Mr. W. E. STYER of the Ohio Agricultural Research and Development Center, Wooster, Ohio, for the scanning electron micrograph photos of the mites.

RÉSUMÉ

OBSERVATIONS SUR LES ACARIENS DES ESPÈCES ASIATIQUES D'ABEILLES (APIS ('ERANA, APIS DORSATA. APIS FIOREA)

On a étudié à Sri Lanka la relation entre les acariens parasites et leurs hôtes naturels les abeilles asiatiques (Apis Cerana, A. dorsata, A. florea).

Varroa jacobsoni n’a été trouvé que chez $A$. cerana. Les recherches sur le couvain ont montré que Varroa est présent de préférence dans les cellules de couvain operculé et que la multiplication a exclusivement lieu dans les cellules de mâles. D'autres recherches faites à Java ont montré qu'A. cerana 
n'ouvre pas les cellules operculées de mâles dans lesquelles la nymphe était morte, ce qui entraînait la mort de l'acarien aussi. Ce mécanisme de régulation manque chez $A$. mellifica, où Varroa jacobsoni se multiplie aussi bien dans les cellules d'ouvrières que dans celles de mâles.

Les autres acariens parasites des abeilles asiatiques à Sri Lanka sont :

1. Euvarroa sinhai parasite les colonies d'Apis florea uniquement, mais il n'a pas été trouvé dans les cellules d'ouvrières,

2. Tropilaelaps koenigerum est présent sur les abeilles adultes et sur les rayons d'A. dorsata,

3. Neocypholaelaps indica, ollinivore et phorétique des abeilles, se trouve en nombre considérable sur toutes les espèces d'abeilles asiatiques (A. cerana, A. dorsata, A. florea). A. dorsata et $A$. florea sont de nouveaux hôtes pour cet acarien.

\section{ZUSAMMENFASSUNG}

\section{BEOBACHTUNGEN ÜBER DIE MILBEN DER ASIATISCHEN ARTEN DER HONIGBIENE (APIS CERANA, APIS DORSATA, APIS FLOREA).}

Die Beziehung von parasitischen Honigbienen-Milben zu ihren natürlichen Wirtarten (Apis cerana, $A$. dorsata und $A$. florea) wurde in Sri Lanka untersucht.

1. Varroa jacobsoni wurde nur bei $A$. cerana gefunden. Brutuntersuchungen zeigten, daß Varroa vorzugsweise in verdeckelten Drohnenzellen vorkommt und die Vermehrung ausschließlich in Drohnenzellen stattfindet. Weitere Untersuchungen in Java ergaben, da $A$. cerana verdeckelte Drohnenzellen, in denen die Puppe gestorben ist, nicht öffnet. Dadurch gehen dann die Varroae ebenfalls zugrunde. Diese Regulationsmechanismen fehlen bei $A$. mellifera, wo sich Varroa jacobsoni sowohl in Arbeiterinnenzellen als auch in Drohnenzellen vermehrt.

2. Euvarroa sinhai wurde nur bei A. florea gefunden. Keine Milbe dieser Art wurde in Arbeiterinnenzellen entdeckt.

3. Tropilaelaps koenigerum wurde nur bei $\boldsymbol{A}$. dorsata gefunden.

4. Neocypholaelaps indica, eine pollenfressende Milbe wurde bei allen drei asiatischen Honigbienenarten gefunden.

\section{REFERENCES}

Akaratanakul P., 1976. - Biology and systematics of bee mites of the family Varroaidae. MS thesis, Oreg. State Univ. Corvallis, $64 \mathrm{p}$.

Delfinado M. D., BAKER E. W., 1974. - Varroaidae a new family of mites on honeybees. Wash. Acad. Sci. 64, 4-10.

Delfinado-Baker M. D., Baker E.W., 1982. - A new species of Tropilaelaps parasitic on honeybees. Am. Bee Journal 122, 416-417.

Hughes A. M., 1976. - The mites of stored food and houses. Ministry of Agric., Fisheries and Food. Tech. Bull. 9, $1-400$.

KoENiger N., 1982. - Interactions among the four species of the genus Apis in the biology of social insects. Eds. Breed M. D., Michener C. D., Evans H. E., Westview Boulder, 59-64.

Koeniger N., Koeniger G. Wijayagunasekara H.N.P., 1981. - Beobachtungen über die Anpassung von Varroa jacobsoni an ihren natürlichen Wirt Apis cerana in Sri Lanka. Apidologie 12 (1), 37-40.

Ritter W., RUtTNeR F., 1980. - Diagnoseverfahren. Allg. dtsch. Imkerzlg., 15, 134-138. 